\title{
Improved IL-2 detection for determination of helper T lymphocyte precursor frequency in limiting dilution assay
}

\author{
M. Winandy, P. Lewalle, V. Deneys * , A. Ferrant, M. De Bruyère \\ Université Catholique de Louvain, Laboratiore d'Immunohématologie, Clos Chapelle-aux-Champs, 30.52, B-1200 Brussels, Belgium \\ Received 24 February 1997; revised 21 January 1998; accepted 30 March 1998
}

\begin{abstract}
In the context of allogeneic bone marrow transplantation, an accurate estimate of the risk of developing graft-versus-host disease (GVHD) is of major interest. The pre-transplant frequency of donor's helper T-lymphocyte precursors (HTLp) directed against host's antigens may be helpful in predicting this risk. This technique relies on an indirect measurement of interleukin-2 (IL-2) secreted by the HTLp, as assessed by the proliferation of an IL-2 dependent cell line. Many authors use the murine CTLL-2 cell line in this assay, but these cells do not respond to the presence of minute amounts of IL-2 in the culture medium, and thus do not discriminate between the absence or the presence of very low levels of IL-2. We therefore decided to compare CTLL-2 with another IL-2 dependent cell line, the murine A9.12 cell line. A comparison was made using serial dilutions of recombinant human IL-2, limiting dilutions of baby hamster kidney (BHK) cells transfected with human IL-2 gene and in the context of clinical tests performed for the detection of pre-transplant HTLp. Both the sensitivity and reliability of the tests were better using A9.12. We conclude that the A9.12 cell line might be a more suitable tool for pre-transplant HTLp determinations before allogeneic bone marrow transplantation or whenever low IL-2 levels are to be measured. (C) 1998 Elsevier Science B.V. All rights reserved.
\end{abstract}

Keywords: IL-2 detection; HTLp; GVHD; A9.12 cell line; CTLL-2 cell line

\section{Introduction}

Allogeneic bone marrow transplantation (BMT) has become a widely used treatment for both malig-

Abbreviations: BHK: baby hamster kidney; BMT: bone marrow transplantation; C.I.: confidence interval; CTLp: cytotoxic T lymphocyte precursor; DMSO: dimethylsulfoxide; GVHD: graftversus-host disease; HLA: human leukocyte antigen; HTLp: helper T lymphocyte precursor; IL-2: interleukin 2; IL-4: interleukin 4; LDA: limiting dilution assay; MLR: mixed lymphocyte reaction; SD: standard deviation

* Corresponding author. Tel.: + 32-2-764-34-47; fax: + 32-2764-30-21; e-mail: deneys@sang.ucl.ac.be. nant and genetic blood disorders. Despite much progress, BMT remains a risky treatment, mainly due to graft rejection, opportunistic infections and the potentially severe syndrome named graft-versushost disease (GVHD) (Ferrara, 1994; Theobald, 1995; den Haan et al., 1995).

Risk factors for GVHD such as disparities between donor and recipient for HLA antigens (Bradley and Jeannet, 1993), the use of an unrelated donor (Bearman et al., 1994), sex mismatch, donor and/or recipient in an older age group (Kalhs, 1993) and previous infections with herpes viruses (Boström et al., 1992; Appleton and Sviland, 1993, Appleton et 
al., 1995) are well established. Nevertheless, any evaluation based on these general risk factors is insufficient to predict GVHD in a given donor-recipient pair.

To predict individual risk of GVHD after BMT, functional in vitro tests have been designed. The most widely used has been the mixed lymphocyte reaction (MLR). Nevertheless, there is no correlation between a high response index measured by MLR and post-transplant complications (GVHD or rejection) (de Gast et al., 1992; Hansen et al., 1995). Limiting dilution assays (LDA) estimating the frequency of cytotoxic or helper T lymphocyte precursors (CTLp or HTLp) have therefore been developed. These tests have been shown to give a better prediction for GVHD or rejection (Goulmy et al., 1985; Kaminski et al., 1989; Theobald et al., 1992; Batchelor et al., 1993; Nierle et al., 1993; Roosnek et al., 1993; Schwarer et al., 1993; Theobald and Bunjes, 1993; Bunjes et al., 1995).

To estimate HTLp frequency, IL-2 secretion is assessed by the proliferation of an IL-2 dependent cell line. The CTLL-2 murine cell line is often used for this purpose but we have noted that these cells lack sensitivity. Therefore we have tested a modification of the usual protocol to improve sensitivity and reliability in the detection of IL-2 secreted by donor anti-host HTLp: the use of the A9.12 murine cell line (a kind gift from Dr. C.C.Y. Shih) instead of the usual CTLL-2 cell line. We compared these two cell lines for IL-2 detection in rhIL-2 serial dilutions, BHK-pBEH limiting dilution supernatants and HTLp supernatants.

\section{Materials and methods}

\subsection{Harvesting and cryopreservation of donor and patient cells}

Heparinized blood from healthy volunteer donors or from patients and their HLA-identical sibling donor was separated on Ficoll-Hypaque (density = 1.077, International Medical, Belgium), washed 3 times and cryopreserved in liquid nitrogen at $5 \times 10^{6}$ cells $/ \mathrm{ml}$ in Dulbecco modified Eagle's medium (DMEM; Gibco) containing 20\% heat-inactivated normal $\mathrm{AB}$ human pooled serum, glutamine (1.5 $\mathrm{mM})$, penicillin $(50 \mathrm{U} / \mathrm{ml})$, streptomycin $(50$ $\mu \mathrm{g} / \mathrm{ml})$, gentamycin $(500 \mu \mathrm{g} / \mathrm{ml})$ and $10 \%$ dimethylsulfoxide.

\subsection{CTLL-2 culture}

The CTLL-2 cell line was maintained in DMEM supplemented with $10 \%$ heat-inactivated fetal calf serum, glucose $(3.5 \mathrm{~g} / 1)$, 2-mercaptoethanol $(2 \times$ $\left.10^{-5} \mathrm{M}\right)$, arginine $(0.55 \mathrm{mM})$, asparagine $(0.24 \mathrm{mM})$, glutamine $(1.5 \mathrm{mM})$, hepes buffer $(10 \mathrm{mM})$, penicillin $(50 \mathrm{U} / \mathrm{ml})$, streptomycin $(50 \mu \mathrm{g} / \mathrm{ml})$, and gentamycin $(500 \mu \mathrm{g} / \mathrm{ml})$. Recombinant human IL-2 (Proleukin ${ }^{\circledR}$, Eurocetus) was added to reach a final concentration of $100 \mathrm{IU} / \mathrm{ml}$. Cells were fed every two or three days and were not allowed to exceed the maximal concentration of $4 \times 10^{5}$ cells $/ \mathrm{ml}$.

\subsection{A9.12 culture}

This murine helper $\mathrm{T}$ cell line was obtained from an SJL anti-AKR limiting dilution microcytotoxicity assay. The cells proliferated in response to alloantigen, IL-2 or Con A. The response to antigen or mitogen was abrogated by CsA and this abrogation could be reversed by adding IL-2. This cell line was maintained in culture for more than 1 year (Shih et al., 1983).

The A9.12 cell line was cultured in RPMI 1640 supplemented with $10 \%$ heat-inactivated fetal calf serum, glutamine $(1.5 \mathrm{mM})$, hepes buffer $(10 \mathrm{mM})$, sodium pyruvate $(2 \mathrm{mM}), 2$-mercaptoethanol $(5 \times$ $\left.10^{-5} \mathrm{M}\right)$, penicillin $(50 \mathrm{U} / \mathrm{ml})$, streptomycin $(50$ $\mu \mathrm{g} / \mathrm{ml})$, and gentamycin $(500 \mu \mathrm{g} / \mathrm{ml})$. IL-2 was added to reach a final concentration of $100 \mathrm{IU} / \mathrm{ml}$.

Cells were fed every 2 or 3 days and were not allowed to exceed the maximal concentration of $4 \times 10^{5}$ cells $/ \mathrm{ml}$. Population doubling occurred over 16 to $18 \mathrm{~h}$. In the early subculturings, $2 \mathrm{ml}$ aliquots were frozen in complete culture medium containing $10 \%$ DMSO and were kept in liquid nitrogen until used. About $3-4 \times 10^{6}$ cells were frozen in each aliquot. Every 6 or 7 weeks, a new batch was started by thawing a previously frozen aliquot to ensure that all cells were IL-2 dependent. 


\subsection{BHK culture}

This cell line was a kind gift from Dr. H. Hauser. It was transfected with the human IL-2 gene and was found to secrete $4.5 \times 10^{3}$ units $/ 10^{6}$ cells $/ 24 \mathrm{~h}$ (Conradt et al., 1989). This cell line was maintained in $25 \mathrm{~cm}^{2}$ culture flasks (Falcon) in the same medium as the A9.12 cell line, except for IL-2 addition. The population doubling time was 14 to $16 \mathrm{~h}$. Every 2 or 3 days, cells were trypsinized to separate them from the culture flask, washed 3 times and subcultured. Culture supernatant was filtered through $0.45 \mu \mathrm{m}$ filter (Millipore) and kept at $-70^{\circ} \mathrm{C}$ until used.

These three cell lines were kept in an humidified atmosphere with $5 \% \mathrm{CO}_{2}$ at $37^{\circ} \mathrm{C}$.

\subsection{Limiting dilution assay with BHK-IL-2 secreting cells}

BHK cells were harvested from the culture flasks, washed three times and diluted to obtain $1.25 \times 10^{4}$ cells/well $/ 100 \mu$ l. This solution was then serially two-fold diluted in flat-bottomed plates (Falcon) with the last dilution containing 0.1 cell/well. Sixteen replicates were set up for each dilution. The limiting dilution plates were incubated for $5 \mathrm{~h}$ at $37^{\circ} \mathrm{C}$ and were then frozen until analysed for IL- 2 content.

\subsection{Limiting dilution assay for HTLp frequency determination}

All cells used in the HTLp assay were thawed on the test day and washed 3 times. Responding cells from the bone marrow donor were diluted to obtain a final concentration of $8 \times 10^{4}$ cells $/$ well $/ 100 \mu l$. These cells were plated in round-bottom plates and serially two-fold diluted with the last dilution at $2.5 \times 10^{3}$ cells /well. Stimulating cells from the patient were irradiated $(20 \mathrm{~Gy}$, rate: $29.6 \mathrm{~Gy} / \mathrm{min}$, source of $\gamma$ radiation: ${ }^{137} \mathrm{Cs}$ ) and $10^{5}$ cells were added in $100 \mu$ l to responding cells. Twenty-four replicates of each dilution were set up, and also 24 replicates with stimulator cells alone for determination of positivity threshold, and 16 replicates with responder cells alone. The stimulating capacity of patient cells was evaluated with 16 replicates con- taining responding cells from two unrelated, HLA mismatched healthy volunteer controls. The responding capacity of donor cells was evaluated with the same controls irradiated to serve as stimulator cells. The cultures were performed in DMEM medium supplemented with $10 \%$ heat-inactivated normal AB human pooled serum, glutamine $(1.5 \mathrm{mM})$, penicillin (50 U/ml), streptomycin $(50 \mu \mathrm{g} / \mathrm{ml})$, and gentamycin $(500 \mu \mathrm{g} / \mathrm{ml})$. Cells were kept in an humidified atmosphere $\left(5 \% \mathrm{CO}_{2}, 37^{\circ} \mathrm{C}\right)$ for $72 \mathrm{~h}$. After $72 \mathrm{~h}, 100 \mu \mathrm{l}$ of the supernatant were removed in new, flat-bottom plates and frozen at $-70^{\circ} \mathrm{C}$ for further analysis. In some experiments, instead of removing supernatants, the plates were irradiated (25 Gy) to prevent lymphocyte proliferation before the indicator cell line was added for the determination of IL-2 in the microcultures.

On the day of analysis, plates containing the supernatants were slowly thawed $\left(4^{\circ} \mathrm{C}\right.$ for $6 \mathrm{~h}, 37^{\circ} \mathrm{C}$ for $30 \mathrm{~min}$ ). During this time, IL-2 dependent cells were washed three times in $50 \mathrm{ml}$ culture medium, counted, diluted to obtain a final concentration of $4 \times 10^{3}$ cells $/$ well $/ 50 \mu l$ and added to the supernatants. A9.12 cells were diluted in an enriched medium (normal culture medium supplemented with $7 \mathrm{mM}$ sodium pyruvate and $3 \mathrm{mM}$ 2-mercaptoethanol). In some experiments, A9.12 cells were starved during $5 \pm 1 \mathrm{~h}$ before being added to the supernatants. They were incubated in a humidified atmosphere $\left(5 \% \mathrm{CO}_{2}, 37^{\circ} \mathrm{C}\right)$ for 24 or $42 \mathrm{~h}$, following experiments, with the last $18 \mathrm{~h}$ in the presence of $2 \mu \mathrm{Ci} /$ well of ${ }^{3} \mathrm{H}$-thymidine. Thymidine incorporation was measured by harvesting cells to filters and counting $\beta$ radiation with a $\beta$ scintillation counter (Beckman LS 6000 SE or Topcount, Packard Instruments).

\subsection{IL-2 or IL-4 detection within serial dilutions}

Two-fold serial dilutions of rh IL-2 or rh IL-4 (Genzyme, Belgium) were prepared in triplicate in $100 \mu \mathrm{l}$ of HTLp culture medium. The dilutions started with an IL-2 concentration of $500 \mathrm{IU} / \mathrm{ml}$ to reach $0.03 \mathrm{IU} / \mathrm{ml}$ or with an $\mathrm{IL}-4$ concentration from $5000 \mathrm{IU} / \mathrm{ml}$ to $0.02 \mathrm{IU} / \mathrm{ml}$. Plates containing dilutions to be tested were frozen at $-70^{\circ} \mathrm{C}$ until used. On the test day, these plates were slowly 
thawed $\left(4^{\circ} \mathrm{C}\right.$ for $6 \mathrm{~h}, 37^{\circ} \mathrm{C}$ for $\left.30 \mathrm{~min}\right)$ and treated in the same way as the LDA supernatants.

\subsection{Statistical analysis}

Evaluations of HTLp frequency were obtained using the $\chi_{2}$ minimalisation for the zero term of the
Poisson distribution between the number of responder cells and the fraction of negative wells (Taswell, 1981, 1984). The result was calculated with GLIM software (NAG, Oxford, UK). $p$ values $>0.1$ were considered as fitting the Poisson model.

In HTLp tests, the threshold of positivity for IL-2 secretion was calculated from the 24 replicates set up
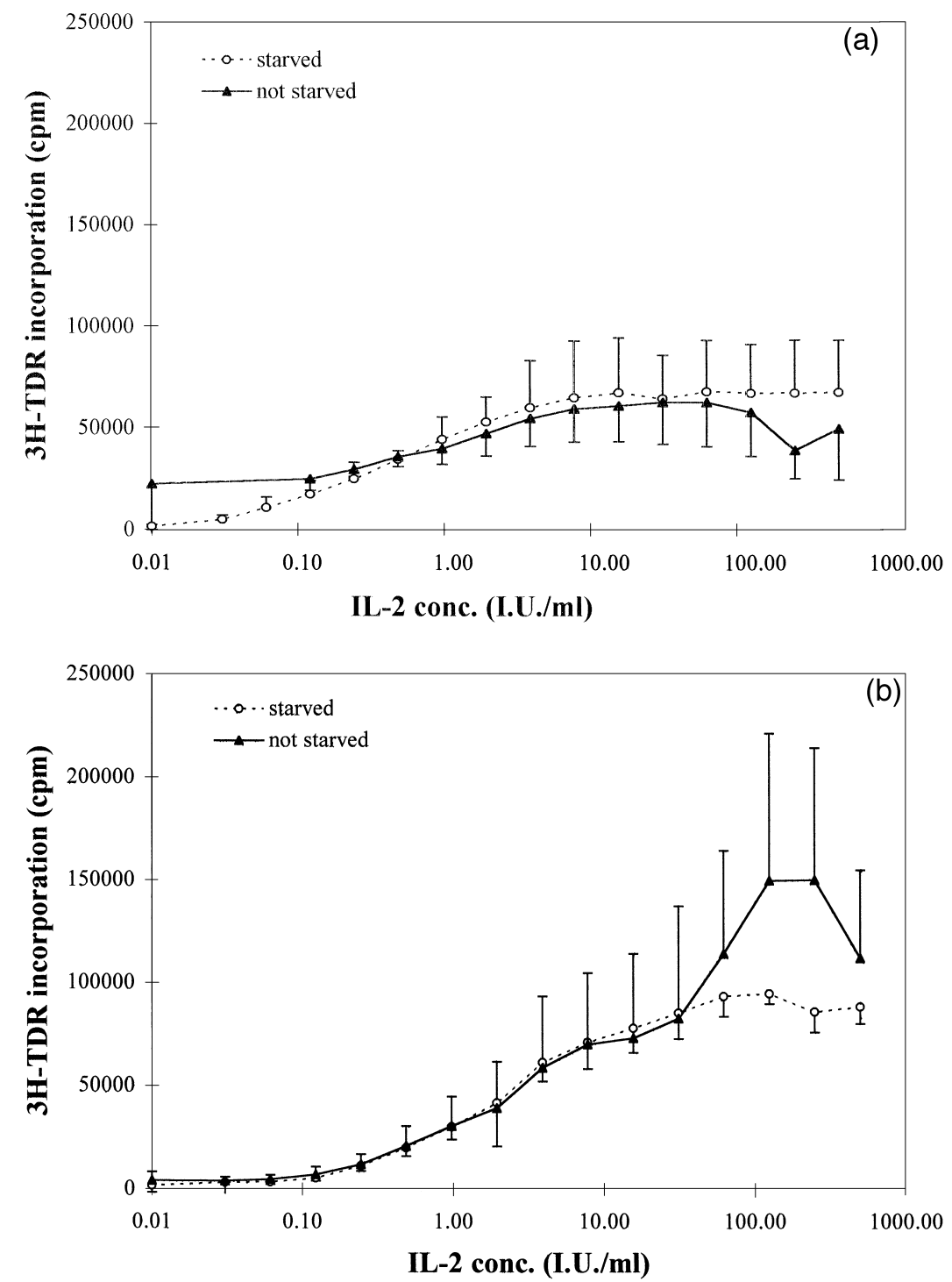

Fig. 1. (a) A total of $4 \times 10^{3}$ A9.12 cells were incubated for $24 \mathrm{~h}$ after being starved (open circles) or not (full triangles) and proliferation was measured by ${ }^{3} \mathrm{H}$-thymine incorporation. Each point represents the mean of three separate experiments and the bar indicates one standard deviation. (b) A total of $4 \times 10^{3}$ A9.12 cells were incubated for $42 \mathrm{~h}$ after being starved (open circles) or not (full triangles), and proliferation was measured by ${ }^{3} \mathrm{H}$-thymidine incorporation. Each point represents the mean of three separate experiments and the bar indicates one standard deviation. 
without responder cells as follows: percentile $75+$ (percentile 75 - percentile 25).

Comparisons of the mean sensitivity of A9.12 and CTLL-2 cells were made using the Mann-Whitney rank test.

\section{Results}

Although the CTLL-2 line is well known and described (Gillis et al., 1978), we needed to determine optimal conditions for the use of the A9.12 cell
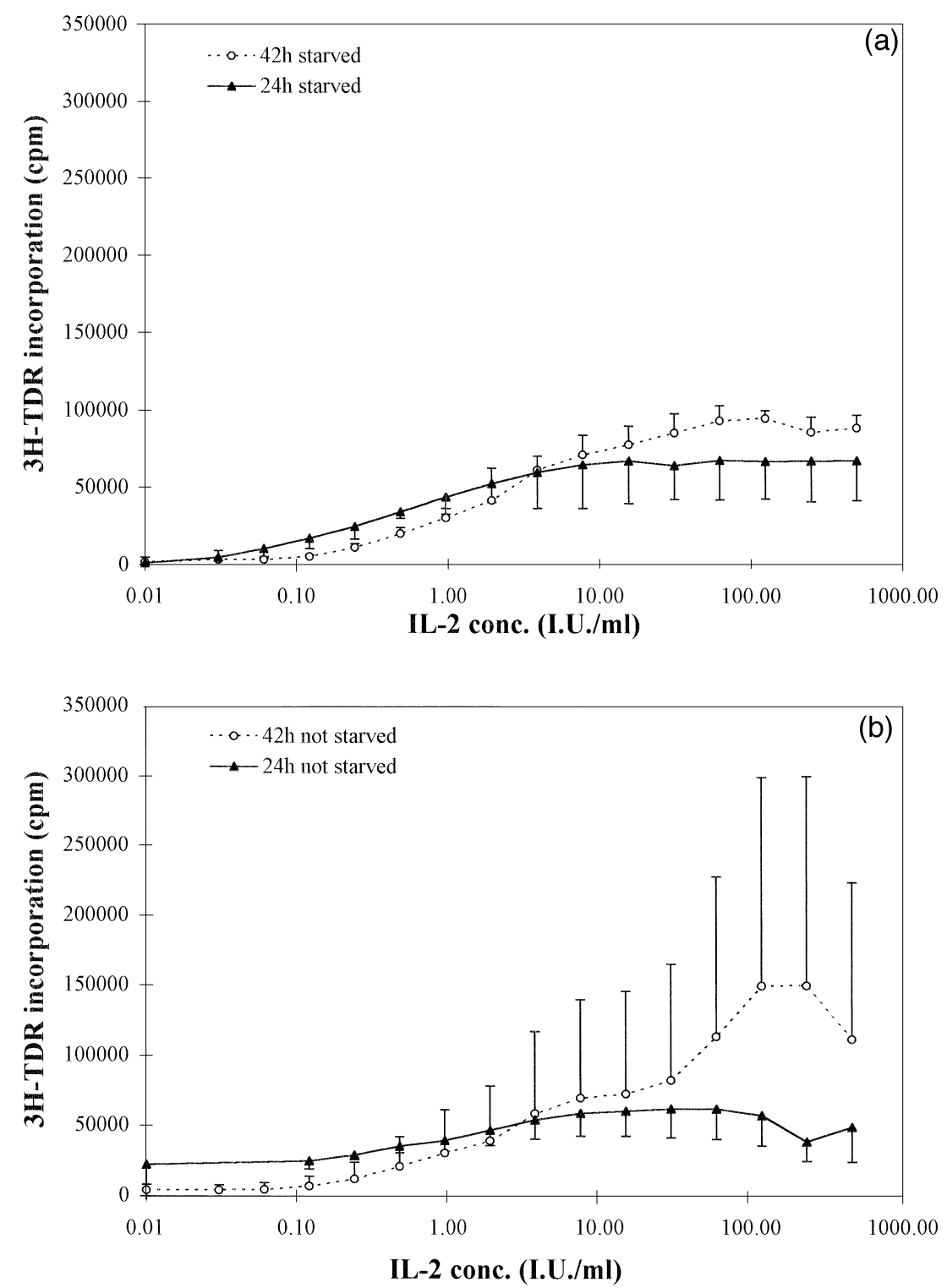

Fig. 2. (a) A total of $4 \times 10^{3}$ A9.12 cells were incubated in IL-2 dilutions for 24 (triangles) or $42 \mathrm{~h}$ (circles), after they had been starved, and proliferation was measured by ${ }^{3} \mathrm{H}$-thymidine incorporation. Each point represents the mean of three separate experiments and the bar indicates one standard deviation. (b) A total of $4 \times 10^{3}$ A9.12 cells were incubated in IL-2 dilutions for 24 (triangles) or $42 \mathrm{~h}$ (lozenges), without starving, and proliferation was measured by ${ }^{3} \mathrm{H}$-thymidine incorporation. Each point represents the mean of three separate experiments and the bar indicates one standard deviation. 
line to detect IL-2. We evaluated the cell number that would give a good sensitivity, the starvation period and the total incubation time to detect IL-2 with the highest discriminatory power, and also the best correlation with IL-2 in the culture wells. We finally ensured that A9.12 cells did not proliferate in response to human IL-4.

\subsection{Starvation of sensitive cells}

We compared the use of the A9.12 cell line with or without starvation before adding the cells to IL-2 dilutions. A total of $4 \times 10^{3}$ A9.12 cells were incubated for 24 (Fig. 1a) or 42 h (Fig. 1b), after being starved for $5 \pm 1 \mathrm{~h}$ or not. If the total incubation time was $24 \mathrm{~h}$, there was an elevated background, and the discrimination power in the first part of the curve was lower. If cells were incubated for $42 \mathrm{~h}$ (Fig. 1b), there was little difference between starved or fed cells. The dosage range was larger for cells that were not starved, but with these culture conditions, there was more variation between wells and between different experiments. We therefore decided to work with starved cells.

\subsection{Incubation time}

We compared two different incubation times: $24 \mathrm{~h}$ (which is often used with the CTLL-2 cell line) or 42 h. Fig. $2 a$ and $b$ show results obtained in three distinct experiments. Proliferation of $4 \times 10^{3}$ cells / well was measured after 24 or $42 \mathrm{~h}$ of incubation in IL-2 dilutions, with (Fig. 2a) or without (Fig. 2b) starving. With $24 \mathrm{~h}$ incubation, cells that were not starved did not exhibit enough sensitivity (elevated background, weak slope of the curve). The small IL-2 concentrations were detected, but there was a plateau effect at lower concentrations compared to cells incubated for $42 \mathrm{~h}$. There were also greater intra- and interassays variations when cells were incubated for $24 \mathrm{~h}$ only.

\subsection{Number of cells required}

We plated $1-16 \times 10^{3}$ cells in serial IL-2 dilutions after they had been starved for $5 \pm 1 \mathrm{~h}$, and allowed them to grow for 42 h. Fig. 3 shows proliferation in response to IL-2. Obviously, $1 \times 10^{3}$ or $2 \times 10^{3}$ cells were associated with less sensitivity than $4 \times 10^{3}$ cells. A total of $4 \times 10^{3}$ cells re-

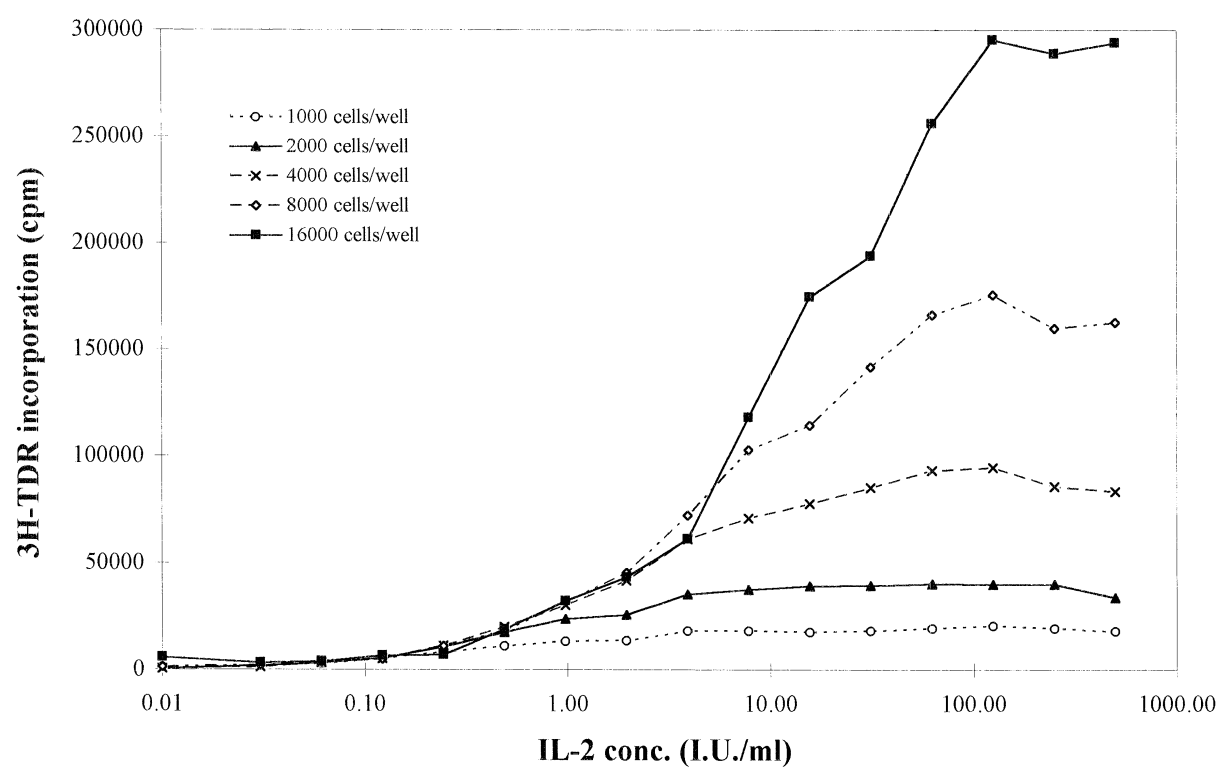

Fig. 3. About $1-16 \times 10^{3}$ A9.12 cells were incubated in IL-2 serial dilutions for $42 \mathrm{~h}$ after being starved, and proliferation was measured by ${ }^{3} \mathrm{H}$-thymidine incorporation. Each point represents the mean of three separate experiments. 


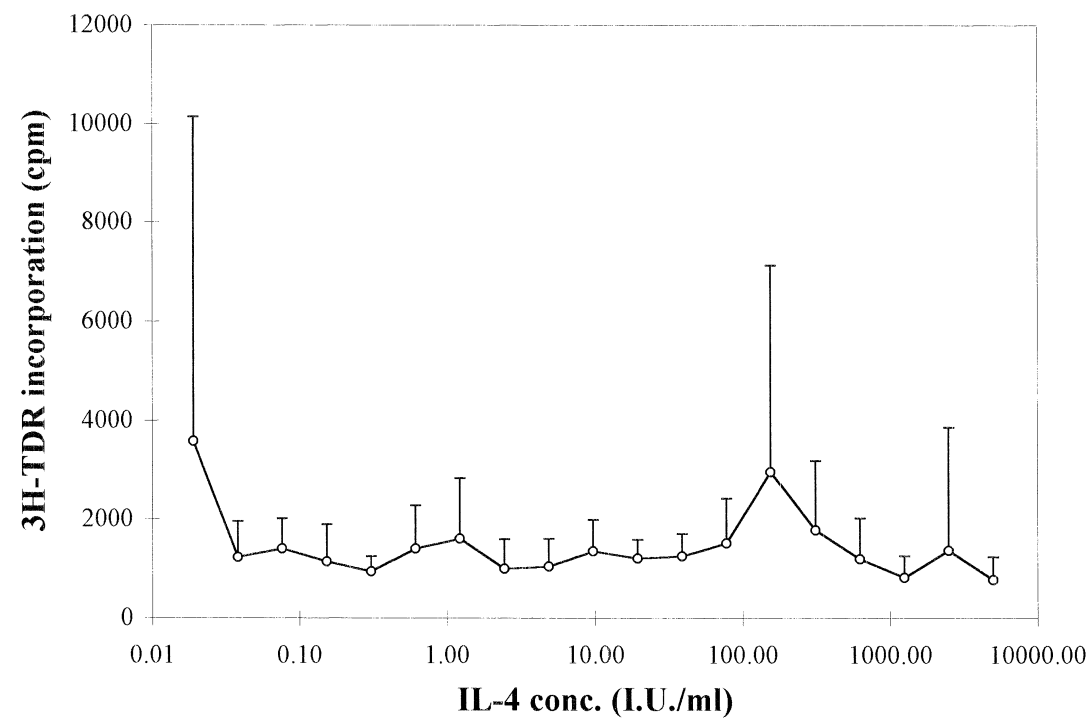

Fig. 4. A total of $4 \times 10^{3}$ A9.12 cells were incubated for $42 \mathrm{~h}$ in the presence of rhIL-4 serial dilutions, and proliferation was measured by ${ }^{3} \mathrm{H}$-thymidine incorporation. Each point represents the mean of three separate experiments and the bar indicates one standard deviation.

sponded to a wider range of IL-2 concentrations (no maximum effect until approximately $50 \mathrm{IU} / \mathrm{ml}$ ). When a larger number of cells was used, the maximal proliferation was proportional to the cell number, but occurred within the same range of IL-2 concentration (about $50 \mathrm{IU} / \mathrm{ml}$ ). On the other hand, the first part of the curve (from 0.2 to $7 \mathrm{IU} / \mathrm{ml}$ ) was almost the same with $4 \times 10^{3}, 8 \times 10^{3}$ or $16 \times 10^{3}$ cells per well. Thus, for the measurement of small amounts of IL-2, we did not increase the cell number

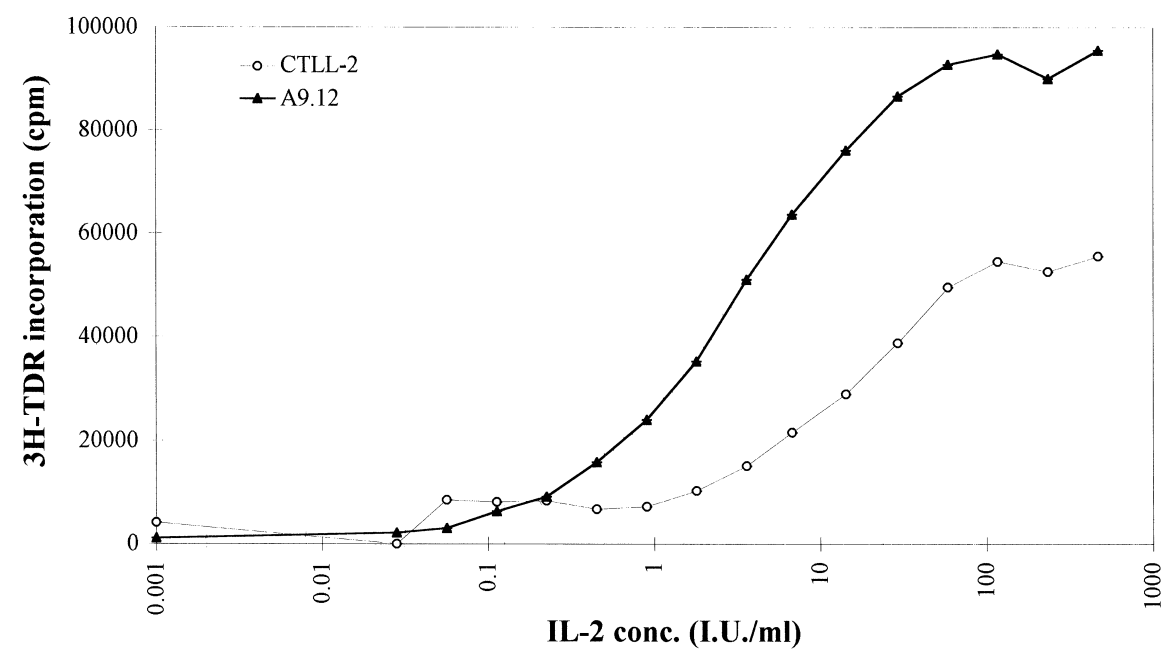

Fig. 5. A total of $4 \times 10^{3}$ cells were incubated in IL-2 dilutions (for $24 \mathrm{~h}$ in the case of CTLL-2 (open circles), and $42 \mathrm{~h}$ in the case of A9.12 (full triangles)), and proliferation was measured by ${ }^{3} \mathrm{H}$-thymidine incorporation. Each point represents the mean of eight separate experiments. 
beyond $4 \times 10^{3}$ per well. If IL-2 concentrations in the range $10-500 \mathrm{IU} / \mathrm{ml}$ were to be measured, it would be preferable to use $16 \times 10^{3}$ cells or more per well.

\subsection{Sensitivity to rhIL-4}

Some authors have reported a sensitivity and growth dependence of CTLL-2 to human IL-4 (Menu et al., 1990; Theobald and Bunjes, 1993). To ensure that A9.12 cells did not grow in response to this cytokine, we performed serial dilutions of IL-4 as we did for IL-2 and tested $4 \times 10^{3}$ A9.12 cells growth within 42 h. Fig. 4 shows that there was no relationship between rhIL-4 concentration and A9.12 proliferation, in comparison with that obtained with IL-2.

\subsection{Sensitivity of IL-2 dependent cell lines}

Fig. 5 compares the two IL-2 sensitive cell lines. A total of $4 \times 10^{3}$ cells were plated in IL-2 dilutions and incubated for $24 \mathrm{~h}$ for CTLL-2 or for $42 \mathrm{~h}$ for A9.12 (this cell line having been starved for $5 \pm 1$ h). The sensitivity of eight cell batches derived from different frozen aliquots was measured. The total observation period lasted for at least 6 months. Over this period, A9.12 cells proved more sensitive than CTLL-2, especially at low concentrations, with lower background and higher maximal proliferation. The dose-proliferation plot showed a longer linear portion with the A9.12 cell line (from 0.06 to 100 $\mathrm{IU} / \mathrm{ml}$ vs. 1 to $100 \mathrm{IU} / \mathrm{ml}$ for CTLL-2), permitting dosage over a wider concentration range. IL-2 detection (given by the first dilution that stimulated higher proliferation than the background) was always better with A9.12 cells $(0.05 \mathrm{IU} / \mathrm{ml}$ vs. $1.22 \mathrm{IU} / \mathrm{ml}$, $p<0.001$, Mann-Whitney rank test) (Table 1).

In Fig. 6, the distribution of proliferating A9.12 or CTLL-2 cultures in response to low doses of rhIL-2 $(0$ or $0.5 \mathrm{IU} / \mathrm{ml})$ is shown. The data were pooled from sixteen separate experiments. CTLL-2 cells responded in a largely overlapping fashion to 0 or $0.5 \mathrm{IU} / \mathrm{ml}$ of IL-2 (Fig. 6a). Conversely, the A9.12 cell line proliferated at completely distinct levels in response to 0 or $0.5 \mathrm{IU} / \mathrm{ml}$ (Fig. 6b). These data demonstrated again the greater sensitivity of the A9.12 cell line to small amounts of IL-2.

\subsection{Reproducibility of IL-2 detection}

Table 1 represents batch-to-batch variability in IL-2 detection for the two cell lines. Maximal and minimal proliferation were compared for the two cell

Table 1

Batch-to-batch reproducibility of IL-2 detection

\begin{tabular}{|c|c|c|c|c|c|c|}
\hline & \multicolumn{2}{|c|}{$\begin{array}{l}{ }^{3} \mathrm{H}-\mathrm{TDR} \text { incorporation in } \\
\text { medium with } 100 \mathrm{IU} / \mathrm{ml} \\
\text { rhIL-2 }(\mathrm{cpm})\end{array}$} & \multicolumn{2}{|c|}{$\begin{array}{l}{ }^{3} \mathrm{H} \text {-TDR incorporation in } \\
\text { medium with } 0 \mathrm{IU} / \mathrm{ml} \\
\text { rhIL-2 }(\mathrm{cpm})\end{array}$} & \multicolumn{2}{|c|}{ IL-2 detection (IU/ml) } \\
\hline Batch 1 & 33821 & 99438 & 1349 & 747 & 0.48 & 0.06 \\
\hline Batch 2 & 58995 & 92293 & 1639 & 863 & 0.48 & 0.06 \\
\hline Batch 3 & 48305 & 106681 & 2203 & 423 & 0.73 & 0.03 \\
\hline Batch 6 & 62490 & 82817 & 3234 & 530 & 1.80 & 0.03 \\
\hline Batch 7 & 35878 & 127317 & 3282 & 381 & 3.60 & 0.06 \\
\hline Batch 8 & 44388 & 74113 & 11430 & 100 & 0.45 & 0.03 \\
\hline Mean & 54607 & 93300 & 4099 & 515 & 1.22 & 0.05 \\
\hline $\mathrm{SD}$ & 18254 & 18324 & 3748 & 254 & 1.12 & 0.03 \\
\hline
\end{tabular}

Eight batches were analysed for minimal and maximal proliferation in response to known IL-2 amounts (0 or 100 I.U./ml) as described for Fig. 5. Triplicate cultures were analysed from each batch. Mean and standard deviation (SD) were calculated from the eight batches. IL-2 detection was indicated by the first dilution that stimulated higher proliferation than the background obtained in wells with culture medium only (mean $+3 \mathrm{SD})$. 


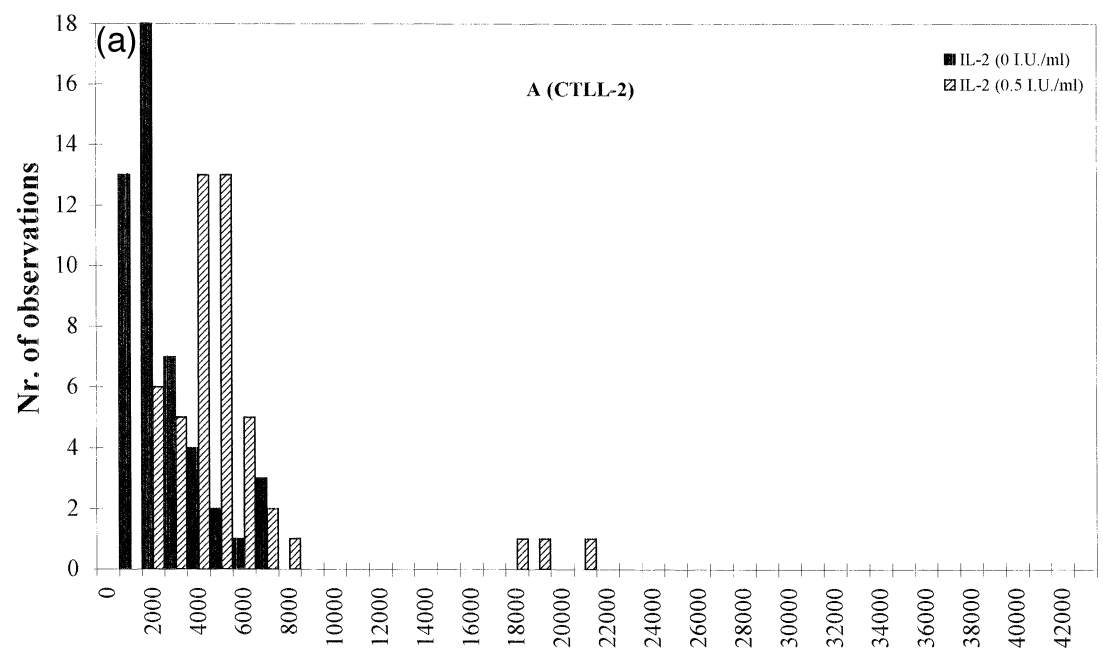

3H-TDR incorporation (cpm)

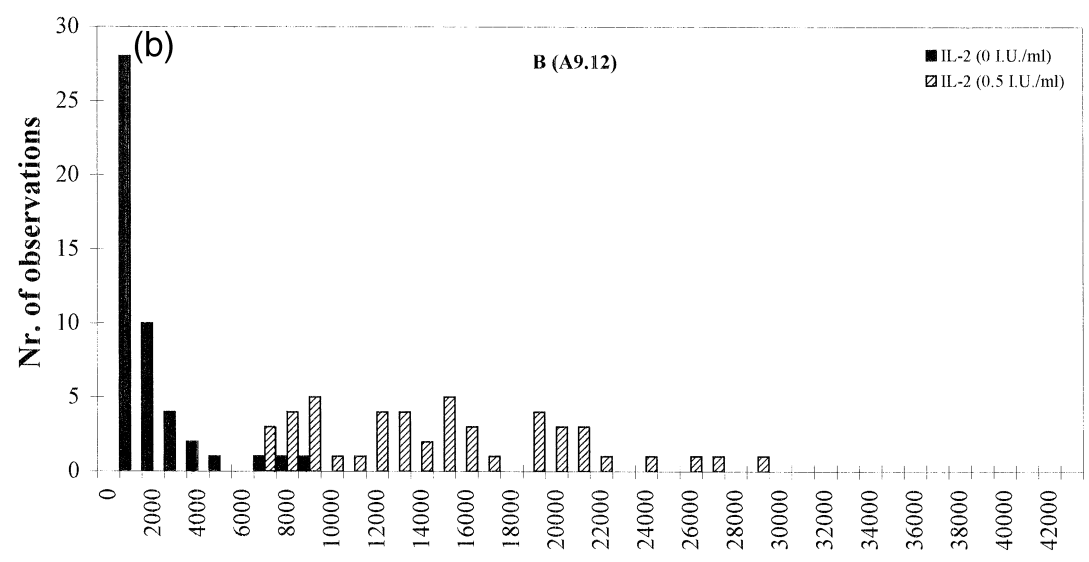

3H-TDR incorporation (cpm)

Fig. 6. Proliferation of individual cultures of CTLL-2 (panel A) or A9.12 (panel B) in response to 0 or 0.5 IU/ml rhIL-2. Proliferation was measured by ${ }^{3} \mathrm{H}$-thymidine incorporation after 24 or $42 \mathrm{~h}$ incubation. Data are pooled from 16 separate experiments.

lines. More important batch-to-batch differences were observed with CTLL-2 cells vs. A9.12 cells, with an elevated ratio of standard deviation to mean (33\% vs. $20 \%$ for maximal proliferation, $91 \%$ vs. $49 \%$ for background, respectively). IL-2 detection was less reproducible with CTLL-2 cells (ratio of standard deviation to mean: $92 \%$ vs. $59 \%$ for A9.12).

All these experiments led us to choose the following experimental conditions to measure IL-2 produc- tion in HTLp supernatants: starving cells for $5 \pm 1 \mathrm{~h}$, total incubation time of $42 \mathrm{~h}$, and the use of $4 \times 10^{3}$ cells per well.

Next, we ensured that this cell line could detect IL-2 secretion from a single cell. For this purpose, a BHK cell line transfected with the human IL-2 gene was plated in limiting dilution experiments. We then compared the A9.12 cell line with the CTLL- 2 cell line for IL-2 detection in these assays. 
Table 2

Comparison of the ability to detect one IL-2 secreting cell in limiting dilution experiments set up with a transfected BHK cell line

\begin{tabular}{lll}
\hline & \multicolumn{2}{l}{ BHK cell frequency } \\
\cline { 2 - 3 } & CTLL-2 & (95\% confidence interval) \\
\hline Expt 1 & $2.68(1.94-3.7)$ & $0.18(0.13-0.26)$ \\
Expt 2 & $10.6(7.1-15.7)$ & $1.83(1.32-2.53)$ \\
Expt 3 & - & $1.54(1.2-2.3)$ \\
\hline
\end{tabular}

BHK cells were incubated in limiting dilution numbers (from $1.25 \times 10^{4}$ to 0.1 cells per well) for $5 \mathrm{~h}$. A total of $4 \times 10^{3} \mathrm{~A} 9.12$ or CTLL- 2 cells were added to LDA plates, incubated for 24 or 42 $\mathrm{h}$, and proliferation was measured by ${ }^{3} \mathrm{H}$-thymidine incorporation. BHK frequency was estimated with the zero term of Poisson law.

\subsection{Capacity to measure IL-2 in IL-2-producing- BHK limiting dilution supernatants}

To assess whether the two cell lines were able to detect IL-2 production from one IL-2 secreting cell, we set up limiting dilution experiments with a transfected BHK cell line that was producing glycosylated human IL-2 at high levels (Conradt et al., 1989). The same experiments were done three times to ensure reproducibility. The A9.12 cell line was clearly able to detect a single IL-2 producing cell, but this was not the case with CTLL-2 (Table 2).

\subsection{Capacity to measure IL-2 in HTLp supernatants}

\subsubsection{Positivity threshold determination}

Our final aim was to evaluate pretransplant HTLp frequency with the greatest sensitivity and reliability. This frequency is calculated using the ratio of negative cultures to the total number of cultures for a given number of responder cells. Thus, the determination of the positivity threshold is of crucial importance. In the negative control wells, the majority of cultures could not support A9.12 cell growth, but some 'outlier' wells displayed ${ }^{3} \mathrm{H}$-thymidine incorporation as high as $8 \times 10^{3} \mathrm{cpm}$ (data not shown). When we calculated the positivity threshold by adding three standard deviations to the mean of the negative control wells, we obtained very high values. These threshold values were also very different from one experiment to another. Accordingly we chose to calculate the positivity threshold with the outlier labelling method (Iglewicz and Hoaglin, 1993). This is based on the median negative value observed and accounts for the false positive values, but is less influenced by them.

\subsubsection{Comparison between supernatant removal and second irradiation}

As IL-2 detection is based on cell line proliferation, it is important to avoid any proliferation from alloreactive lymphocytes in the HTLp assay. For this purpose, some authors perform a second irradiation of LDA plates (Schwarer et al., 1993; Gribben et al., 1996; Potolicchio et al., 1996). Other investigators harvest supernatant and add this directly to the indicator cell line (Theobald et al., 1992) or freeze it (Schanz et al., 1994; Bouma et al., 1996; Lewalle et al., 1996; Young et al., 1996; van der Meer et al., 1997). This method permits an easier management of LDA experiments.

Second irradiation or supernatant freezing was compared for the A9.12 and CTLL-2 cell lines. HTLp frequency was determined in one HLA fully mismatched healthy donor pair. Four identical sets of limiting dilution plates were set up to permit compar-

Table 3

HTLp assay with one HLA incompatible healthy control pair was performed in four sets. After $72 \mathrm{~h}$ incubation of alloreactive lymphocytes, either a second irradiation or supernatant removal and freezing was performed. Then $4 \times 10^{3}$ IL-2 sensitive cells were added to the LDA plates, incubated for 24 (CTLL-2) or $42 \mathrm{~h}$ (A9.12), and proliferation was measured by ${ }^{3} \mathrm{H}$-thymidine incorporation. HTLp frequency was estimated with the zero term of Poisson law

\begin{tabular}{lll}
\hline & $1 /$ HTLp frequency $10^{-3}$ (95\% confidence interval) \\
\cline { 2 - 3 } & CTLL-2 & A9.12 \\
\hline (a) Irradiated plates & $27.4(20.2-37.2)$ & $6.4(4.7-8.7)$ \\
(b) Frozen supernatants & $25.2(19-33.5)$ & $4.5(3.3-6.1)$ \\
\hline
\end{tabular}


ison under identical conditions. Table 3 shows the results obtained: for each cell line, the HTLp frequency is equivalent, with $95 \%$ confidence intervals largely overlapping either when supernatants were removed and frozen or when plates were irradiated again. Here also, the A9.12 cell line proved to be more sensitive, detecting four-fold higher HTLp frequencies. As supernatant freezing was far easier to manage, allowing many plates to be analysed on the same day, this method was chosen for all HTLp experiments.

\subsubsection{Ability to measure IL-2 in supernatants from HTLp assays}

The CTLL-2 or A9.12 cell lines were used to estimate HTLp frequency from 107 different donorrecipient pairs (healthy controls or patients with blood disease). Table 4 (part 1) shows that CTLL-2 gave numerous problems: absence of proliferation in $48 \%$ of the experiments and poor concordance with the zero term of Poisson law in $40 \%$ of the experiments. Conversely, the A9.12 cell line never failed to respond to IL-2 present in culture supernatants. Moreover the concordance with Poisson law was obtained in $81 \%$ of the experiments.
Twenty-six experiments were set up to determine donor anti-host pretransplant HTLp frequency for bone marrow recipients. The results obtained were compared with the occurrence of acute GVHD (Table 4, part 2). When CTLL-2 cells were used as the indicator cell line, there was an important lack of specificity in predicting GVHD (20\% vs. $71 \%$ for the A9.12 cell line). Poor predictive values were obtained (43\% for positive predictive values, $50 \%$ for negative predictive values, compared to 80 and $71 \%$ for A9.12 cells, respectively).

Sensitivity for HTLp detection was compared for the two cell lines in 84 HTLp experiments (59 with A9.12 and 25 with CTLL-2) (Table 4, part 3). The threshold for HTLp detection (that is proliferation in negative controls) was calculated for these experiments. Median background proliferation was higher with CTLL-2 cells (3346 cpm vs. $2652 \mathrm{cpm}$ with A9.12 cells). Median proliferation in microcultures from the dilution containing one HTLp per well was calculated. Higher responses were obtained with A9.12 cells (5858 cpm vs. 4841 for CTLL-2). Thus a better discrimination between positive and negative microcultures was obtained (ratio of proliferation in positive wells relative to negative control wells: 1.44 for the CTLL-2 cell line, 2.2 for the A9.12 cell line).

Table 4

Helper T lymphocyte precursor frequency was estimated in healthy volunteers and in prospective BMT patients with the A9.12 or the CTLL-2 lines

\begin{tabular}{llll}
\hline & & \multicolumn{2}{l}{ Cell line used for IL-2 detection } \\
\cline { 3 - 4 } & & CTLL-2 & A9.12 \\
\hline Part 1 & Nr. LDA experiments without cell proliferation in positve controls & $23 / 48(48 \%)$ & $0 / 59(0 \%)$ \\
& Nr. LDA experiments not matching the zero term of Poisson law & $10 / 25(40 \%)$ & $11 / 59(19 \%)$ \\
& Nr. LDA experiments matching the zero term of Poisson law & $15 / 25(60 \%)$ & $48 / 59(81 \%)$ \\
Part 2 & Low HTLp frequency-GVHD 0-I (true negative) & $1 / 9(11 \%)$ & $5 / 17(32 \%)$ \\
& Low HTLp frequency-GVHD II-IV (false negative) & $1 / 9(11 \%)$ & $2 / 17(11 \%)$ \\
& High HTLp frequency-GVHD 0-I (false positive) & $4 / 9(44 \%)$ & $2 / 17(11 \%)$ \\
& High HTLp frequency - GVHD II-IV (true positive) & $3 / 9(33 \%)$ & $8 / 17(47 \%)$ \\
& Sensitivity & $3 / 4(75 \%)$ & $8 / 10(80 \%)$ \\
& Specificity & $1 / 5(20 \%)$ & $5 / 7(71 \%)$ \\
& Positive predictive value & $3 / 7(43 \%)$ & $8 / 10(80 \%)$ \\
Part 3 & Negative predictive value & $1 / 2(50 \%)$ & $5 / 7(71 \%)$ \\
& Threshold of HTLp detection (median cpm) & 3346 & 2652 \\
& Proliferation in one HTLp containing culture well (median cpm) & 4841 & 5858 \\
\hline
\end{tabular}

Part 1: Validity of HTLp experiments (data from 107 experiments).

Part 2: Use of pretransplant HTLp results in BMT patients for GVHD prediction (data from 26 experiments).

Part 3: Capacity to proliferate in response to IL-2 produced by a single HTLp (data from 84 experiments). 


\section{Discussion}

The CTLL-2 cell line is widely used to detect IL-2 in culture supernatants. As also noted by Weston and Farrell (1996), we observed that the sensitivity of this cell line is not stable over time, especially following subculturing (data not shown). Moreover, in many HTLp supernatants, this cell line was unable to detect the small amounts of IL-2 produced. As this test was performed only once (due to the large number of patient's cells required), it was essential to detect IL-2 in the supernatants by the most accurate method. The A9.12 cell line met these requirements of sensitivity and reproducibility and therefore its use should be recommended whenever the IL-2 levels are very low. Other investigators (Lewalle et al., 1996; Keever-Taylor et al., 1997) have used it with success in HTLp detection assays.

The greater sensitivity of A9.12 might explain the proliferation observed in some negative control wells in the HTLp test. Some stimuli other than allogeneic cell recognition might be associated with these cultures. For instance, there might be recognition of allogeneic serum proteins present in the culture medium. The irradiation stress might also provoke release of a small amount of IL-2. This was shown in vivo (Xun et al., 1994) as well as in vitro (Galdiero et al., 1994). Hornick et al. (1997) also noted a source of 'unwanted' IL-2 both in the stimulating and in the responding population. They also noted a 'back stimulation' of stimulating cells activated by alloantigens from responder cells, leading to poor concordance with single-hit kinetics. To avoid these IL-2 sources, they depleted the responding population of HLA class II positive cells and the T cells from the stimulating population. These depletions allowed HTLp to achieve better concordance with the single-hit model. On the other hand, this led to a decrease of sensitivity and an increase of the number of stimulating cells required for the successive rounds of depletion. Moreover, this model deviates from the in vivo conditions encountered in bone marrow or solid organ transplantation.

Rather than performing depletions, we changed the determination of the positivity threshold. The new method of calculation takes into account the median proliferation rather than the mean because the mean showed larger variations due to a few elevated values. Thus, the outlier labelling method was chosen. It gave a better inter experimental stability in positivity thresholds. Using this cell line, the number of cells, the starving duration and the incubation time were critical.

An accurate measurement of IL-2 might also prove useful in the evaluation of patients suffering from other immunological diseases such as AIDS, in which IL-2 plays an important role (Westendorp et al., 1994; Brinchmann et al., 1994; Collette et al., 1996; Yoo et al., 1996). In kidney and cardiac allografts, local and systemic IL-2 production has been correlated with rejection episodes and indicates the need to continue immunosuppression (Muluk et al., 1991; Schulick et al., 1993; DeBruyne et al., 1995). There is also an increasing interest in IL-2 dosage in autoimmune diseases such as multiple sclerosis, thyroiditis, myasthenia gravis, type I diabetes, thrombocytopenic purpura (Burns and Littlefield, 1993; De Maria et al., 1994; Lohr et al., 1994; Yi et al., 1994; Rep et al., 1996; Semple et al., 1996). The follow-up of IL-2 and other cytokines in all these diseases might permit a better understanding of the pathological processes and lead to better disease management.

In conclusion, we have established that the A9.12 line is preferable for detecting low IL-2 production in the HTLp assay compared to the conventionally used CTLL-2 cell line.

\section{Acknowledgements}

We would like to thank Dr. P. Martiat for carefully reading this manuscript and Dr. D. Climov for valuable statistical advices. We are grateful to Dr. Shih and Dr. Hauser for the gift of cell lines. This work was supported by F.N.R.S./Télévie grants nr 7.4509.93 and 7.4538.95 and by Salus Sanguinis Foundation.

\section{References}

Appleton, A.L., Sviland, S., 1993. Pathogenesis of GVHD: role of herpes viruses. Bone Marrow Transplant. 11, 349.

Appleton, A.L., Sviland, S., Peiris, J.S.M., Taylor, C.E., Wilkes, J., Green, M.A., Pearson, A.D.J., Procotor, S.J., Hamilton, P.J., Cant, A.J., Malcolm, A.J., 1995. Role of target organ 
infection with cytomegalovirus in the pathogenesis of GVHD. Bone Marrow Transplant. 15, 557.

Batchelor, J.R., Schwarer, A.P., Yin, Z.J., Barrett, A.J., Goldman, J.M., Lechler, R.I., 1993. Helper T-lymphocyte precursor frequencies predict risks of GVHD in bone marrow transplantation. Transplant. Proc. 25, 1237.

Bearman, S., Mori, M., Beatty, P.G., Meyer, W.G., Buckner, C.D., Petersen, F.B., Sanders, J.E., Anasetti, C., Martin, P., Appelbaum, F.R., Hansen, J.A., 1994. Comparison of morbidity and mortality after marrow transplantation from HLAgenotypically identical unrelated donors. Bone Marrow Transplant. 13, 31.

Boström, L., Ringdén, O., Forsgren, M., 1992. Strong donor mononuclear cell reactivity for herpes simplex virus antigen in immune donor/recipient pair is associated with GVHD. Transplant. Proc. 24, 376.

Bouma, G.J., Shanz, U., Oudshoorn, M., van der Meer-Prins, P.M.W., Roelen, D.L., van Rood, J.J., Claas, F.H.J., 1996. A cell-saving non-radioactive limiting dilution analysis-assay for the combined determination of helper and cytotoxic T lymphocyte precursor frequencies. Bone Marrow Transplant. 17, 19.

Bradley, B.A., Jeannet, M., 1993. Unrelated donor bone marrow transplantation-the role of histocompatibility. Bone Marrow Transplant. 12, 29, suppl. 4.

Brinchmann, J.E., Doblourg, J.H., Heger, B.H., Haaiheim, L.L., Sannes, M., Egeland, T., 1994. Expression of costimulatory molecule CD28 on T cells in human immunodeficiency virus type 1 infection: functional and clinical correlations. J. Infect. Dis. 169,730

Bunjes, D., Theobald, M., Nierle, T., Arnold, R., Heimpel, H., 1995. Presence of host-specific IL-2-secreting T helper cell precursors correlates closely with active primary and secondary chronic GVHD. Bone Marrow Transplant. 15, 727.

Burns, J., Littlefield, K., 1993. A role for antigen presenting cells and bacterial superantigens in reversal of human $\mathrm{T}$ lymphocyte anergy. Eur. J. Immunol. 23, 3300.

Collette, Y., Chang, H.L., Cerdan, C., Chambost, H., Algarte, M., Mawas, C., Imbert, J., Burny, A., Olive, D., 1996. Specific Th1 cytokine down-regulation associated with primary clinically derived human immunodeficiency virus type $1 \mathrm{Nef}$ gene-induced expression. J. Immunol. 156, 360.

Conradt, H.S., Nimtz, M., Dittmar, K.E., Lindemaier, W., Hoppe, J., Hauser, H., 1989. Expression of human IL-2 in recombinant baby hamster kidney, Ltk- and chinese hamster ovary cells. Structure of O-linked carbohydrate chains and their location within the polypeptide. J. Biol. Chem. 29, 17368.

DeBruyne, L.A., Renlund, D.G., Bishop, D.K., 1995. Evidence that human cardiac allograft acceptance is associated with a decrease in donor-reactive T-lymphocytes. Transplantation 59, 778.

de Gast, G.C., Mickelson, E.M., Beatty, P.G., Amos, D., Sullivan, K.M., Schoch, H.G., Thomas, E.D., Hansen, J.A., 1992. Mixed leukocyte culture reactivity and GVHD in HLA-identical marrow transplantation for leukemia. Bone Marrow Transplant. 9, 87.

De Maria, R., Todaro, M., Stassi, G., Di Blasi, F., Giordano, M., Galluzzo, A., Giordano, C., 1994. Defective T cell
receptor/CD3 complex signalling in human type I diabetes. Eur. J. Immunol. 24, 999.

den Haan, J.M.M., Sherman, N.E., Blokland, E., Huczko, E., Koning, F., Drijfhout, J.W., Skipper, J., Shabanowitz, J., Hunt, D.F., Engelhard, V.H., Goulmy, E., 1995. Identification of GVHD-associated human minor histocompatibility antigens. Lancet 268, 1476.

Ferrara, J.L.M., 1994. Paradigm shift for graft-versus-host disease. Bone Marrow Transplant. 14, 183.

Galdiero, M., Cipollaro de l'Ero, G., Folgore, A., Cappello, M., Giobbe, A., Sasso, F.S., 1994. Effect of irradiation doses on alterations in cytokine release by monocytes and lymphocytes. J. Med. 25, 23.

Gillis, S., Ferm, M.M., Ou, W., Smith, K.A., 1978. T cell growth factor: parameters of production and a quantitative microassay for activity. J. Immunol. 120, 2027.

Goulmy, E., Bockland, E., Gratama, J.W., Zwaan, F.E., van Rood, J.J., 1985. Host-directed cytotoxic activity in bone marrowgrafted patients. Transplant. Proc. 17, 725.

Gribben, J.G., Guinan, E.C., Boussiotis, V.A., Ke, X.Y., Linsley, L., Sieff, C., Gray, G.S., Freeman, G.J., Nadler, L.M., 1996. Complete blockade of B7 family mediated costimulation is necessary to induce human alloantigen-specific anergy: a method to ameliorate graft-versus-host disease and extend the donor pool. Blood 87, 4887.

Hansen, J.A., Petersdorf, E.W., Choo, S.Y., Marin, P.J., Anasetti, C., 1995. Marrow transplantation from HLA partially matched relatives and unrelated donors. Bone Marrow Transplant. 15, s128, suppl 2.

Hornick, P.I., Brookes, P.A., Mason, P.D., Taylor, K.M., Yacoub, M.H., Rose, M.L., Batchelor, R., Lechler, R.I., 1997. Optimizing a limiting dilution culture system for quantifying the frequency of interleukin-2-producing alloreactive helper $\mathrm{T}$ lymphocytes. Transplantation 64, 472.

Iglewicz, B., Hoaglin, D.C., 1993. How to detect and handle outliers. The ASQC Basis References in Quality Control: Statistical Techniques, Vol. 16.

Kalhs, P., 1993. GVHD—risk factors. Bone Marrow Transplant. 12, s48, suppl. 4.

Kaminski, E., Hows, J., Man, S., Brookes, P., Hughes, T., Avakian, O., Goldman, J.M., Batchelor, J.R., 1989. Prediction of GVHD by frequency analysis of cytotoxic $\mathrm{T}$ cells after unrelated donor bone marrow transplantation. Transplantation 48, 608 .

Keever-Taylor, C.A., Passweg, J., Kawanishi, Y., Casper, J., Flomenberg, N., Baxter-Lowe, L.A., 1997. Association of donor-derived host-reactive cytolytic and helper $\mathrm{T}$ cells with outcome following alternative donor $\mathrm{T}$ cell-depleted bone marrow transplantation. Bone Marrow Transplant. 19, 1001.

Lewalle, P., Hensel, N., Guimares, A., Couriel, D., Jiang, Y.Z., Mavroudis, D., Barrett, A.J., 1996. Helper and cytotoxic lymphocyte responses to chronic myeloid leukaemia: implications for adoptive immunotherapy with T cells. Br. J. Haematol. 92, 587.

Lohr, H.F., Schlaak, J.F., Gerken, G., Fleischer, B., Dienes, H.P., 1994. Phenotypical analysis and cytokine release of liver-infiltrating and peripheral blood T-lymphocytes from patients with chronic hepatitis of different etiology. Liver 14, 161. 
Menu, E., Jankovic, D.L., Theze, J., David, V., Chaouat, G., 1990. Immunoactive products of human placenta (III): characterization of an inhibitor affecting lymphocyte proliferation. Reg. Immunol. 3, 254.

Muluk, S.C., Clerici, M., Via, C.S., Weir, M.R., Kimmel, P.L., Shearer, G.M., 1991. Correlation of in vitro CD4 + T helper cell function with clinical graft status in immunosuppressed kidney transplant recipients. Transplantation 52, 284.

Nierle, T., Bunjes, D., Arnold, R., Heimpel, H., Theobald, M., 1993. Quantitative assessment of posttransplant host-specific IL-2-secreting $\mathrm{T}$ helper cells precursors in patients with and without acute GVHD after allogeneic HLA-identical sibling bone marrow transplantation. Blood 81, 841 .

Potolicchio, I., Brookes, P.A., Madrigal, A., Lechler, R.I., Sorrentino, R., 1996. HLA-DPB1 mismatch at position 69 is associated with high helper $\mathrm{T}$ lymphocyte precursor frequencies in unrelated bone marrow transplant pairs. Transplantation 62, 1347.

Rep, M.H., Hintzen, R.Q., Polman, C.H., van Lier, R.A., 1996. Recombinant interferon beta blocks proliferation but enhances interleukin-10 secretion by activated human T cells. J. Neuroimmunol. 67, 111.

Roosnek, E., Hogendijk, S., Zawadynski, S., Speiser, D., Tiercy, J.M., Helg, C., Chapuis, B., Gratwhol, A., Gmür, J., Seger, R., Jeannet, M., 1993. The frequency of pretransplant donor cytotoxic $\mathrm{T}$ cell precursors with anti-host specificity predicts survival of patients transplanted with bone marrow from donors other than HLA-identical siblings. Transplantation 56, 691.

Schanz, U., Roelen, D.L., Kardol, M.J., van Rood, J.J., Claas, F.H.J., 1994. The relative radioresistance of interleukin-2 production by human peripheral blood lymphocytes: consequences for the development of a new limiting dilution assay for the enumeration of $\mathrm{T}$ lymphocyte precursor frequencies. J. Immunol. Meth. 169, 221.

Schulick, R.D., Weir, M.B., Miller, M.W., Cohen, D.J., Bermas, B.L., Shearer, G.M., 1993. Longitudinal study of in vitro $\mathrm{CD} 4+\mathrm{T}$ helper cell function in recently transplanted renal allograft patients undergoing tapering of their immunosuppressive drugs. Transplantation 56, 590.

Schwarer, A.P., Jiang, Y.Z., Brookes, P.A., Barrett, A.J., Batchelor, J.R., Goldman, J.M., Lechler, 1993. Frequency of anti-recipient alloreactive helper T-cell precursor in donor blood and GVHD after identical-sibling bone marrow transplantation. Lancet 341, 203.

Semple, J.W., Milev, Y., Cosgrave, D., Mody, M., Hornstein, A., Blanchette, V., Freedman, J., 1996. Differences in serum cytokine levels in acute and chronic autoimmune thrombocytopenic purpura: relationship to platelet phenotype and antiplatelet $\mathrm{T}$ cell reactivity. Blood 87,4245 .
Shih, C.C.Y., Truitt, R.L., Abramoff, P., Bortin, M.M., 1983. Relationship between IL-2 receptors and cyclosporine-induced suppression of $\mathrm{T}$ leukemia and $\mathrm{T}$ helper cells. Transplant. Proc. 15, 2394, suppl 1.

Taswell, C., 1981. Limiting dilution assays for the determination of immunocompetent cell frequencies. I. Data analysis. J. Immunol. 12, 1614.

Taswell, C., 1984. Limiting dilution assays for the determination of immunocompetent cell frequencies: III. Validity tests for single-hit Poisson model. J. Immunol. Meth. 72, 29.

Theobald, M., 1995. Allorecognition and GVHD. Bone Marrow Transplant. 15, 489.

Theobald, M., Bunjes, D., 1993. Pretransplant detection of human minor histocompatibility antigen-specific naive and memory interleukin-2 secreting $\mathrm{T}$ cells within class I major histocompatibility complex (MHC)-restricted $\mathrm{CD} 8+$ and class II MHC-restricted CD4 + T cells subsets. Blood 82, 298.

Theobald, M., Nierle, T., Bunjes, D., Arnold, R., Heimpel, H., 1992. Host-specific IL-2-secreting T cell precursors as predictors of acute GVHD in bone marrow transplantation between HLA-identical siblings. New Engl. J. Med. 327, 1613.

van der Meer, A., Joosten, I., Ruiter, J., Allebes, W.A., 1997. A single $\left({ }^{3} \mathrm{H}\right)$ thymidine-based limiting dilution analysis to determine HTLp and CTLp frequencies for bone marrow donor selection. Bone Marrow Transplant. 20, 149.

Westendorp, M.O., Li Weber, M., Frank, R.W., Krammer, P.H., 1994. Human immunodeficiency virus type 1 Tat upregulates interleukin-2 secretion in activated T cells. J. Virol. 68, 4177.

Weston, L., Farrell, C., 1996. HTLp in human transplantations. Hum. Immunol. 47, 84.

Xun, C.Q., Thompson, J.S., Jennings, C.D., Brown, S.A., Widmer, D.B., 1994. Effect of total body irradiation, busulfancyclophosphamide or cyclophosphamide conditioning on inflammatory cytokine release and development of acute and chronic graft-versus-host disease in $\mathrm{H}$-2-incompatible transplanted SCID mice. Blood 83, 2360.

Yi, Q., Ahlberg, R., Pirskanen, R., Lefvert, A.K., 1994. Acetylcholine receptor-reactive $\mathrm{T}$ cells in myasthenia gravis: evidence for the involvement of different subpopulations of $\mathrm{T}$ helper cells. J. Neuroimmunol. 50, 177.

Yoo, J., Chen, H., Kraus, T., Hirsch, D., Polyak, S., George, I., Sperber, K., 1996. Altered cytokine production and accessory cell function after HIV-1 infection. J. Immunol. 157, 1313.

Young, N.Y., Roelen, D.L., Dallman, M.J., Wood, K.J., Morris, P.J., Welsh, K.I., 1996. Enumeration of human alloreactive T lymphocyte precursor frequencies by limiting dilution analysis of IL-2 production. J. Immunol. Meth. 195, 33. 